This is an electronic reprint of the original article. This reprint may differ from the original in pagination and typographic detail.

Author(s): Jayawardhena, Chanaka; Kuckertz, Andreas; Karjaluoto, Heikki; Kautonen, Teemu

Title: $\quad$ Antecedents to permission based mobile marketing: an initial examination

Year: $\quad 2009$

Version:

Please cite the original version:

Jayawardhena, C., Kuckertz, A., Karjaluoto, H., \& Kautonen, T. (2009). Antecedents to permission based mobile marketing: an initial examination. European Journal of Marketing, 43(3/4), 473-479. https://doi.org/10.1108/03090560910935541

All material supplied via JYX is protected by copyright and other intellectual property rights, and duplication or sale of all or part of any of the repository collections is not permitted, except that material may be duplicated by you for your research use or educational purposes in electronic or print form. You must obtain permission for any other use. Electronic or print copies may not be offered, whether for sale or otherwise to anyone who is not an authorised user. 


\section{Antecedents to permission based mobile marketing: An initial examination}

Chanaka Jayawardhena*, Andreas Kuckertz, Heikki Karjaluoto and Teemu Kautonen

*Corresponding author:

Dr Chanaka Jayawardhena

Loughborough University Business School

Loughborough University

Leicestershire LE11 3TU

UK

e-mail: $\underline{\text { C.Jayawardhena@lboro.ac.uk }}$

Tel: +441509228831

Fax: +44 1509223960

Dr Teemu Kautonen

University of Vaasa

Department of Management

PO Box 700

FIN-65101 Vaasa

Finland

e-mail: teemu.kautonen@uwasa.fi

Tel: +358440244280

Fax: +358 63248195
Dr Andreas Kuckertz University of Duisburg-Essen E-Business and E-Entrepreneurship

Research Group Universitaetsstr. 9

D-45141 Essen

Germany

e-mail: andreas.kuckertz@uni-due.de

Tel: +492011832826

Fax: +492011832862

Dr Heikki Karjaluoto School of Business and Economics PO Box 35 (MaE)

FIN-40014 University of Jyvaskyla

Finland

e-mail: heikki.karjaluoto@econ.jyu.fi

Tel: +358 142602694

Fax: +358 142603331 
Chanaka Jayawardhena is Lecturer in Marketing at Loughborough University Business School, UK. His research interests are in consumer behaviour in new technologies and service evaluation; he has won numerous research awards including two Best Paper Awards at the Academy of Marketing Conference. Previous publications have appeared in the Industrial Marketing Management, Journal of Marketing Management, Journal of General Management, Journal of Internet Research, International Journal of Retailing and Distribution Management, European Business Review, among others.

Andreas Kuckertz is a postdoctoral researcher at the University of Duisburg-Essen, Germany, and a member of the E-Business and E-Entrepreneurship Research Group. He received his doctoral degree with a thesis on venture capital finance from the University of Duisburg-Essen in 2005. His current research focuses on the interface of entrepreneurship and innovation management. Previous publications have appeared in the Journal of Private Equity, International Journal of Technology Management, International Journal of Entrepreneurship and Small Business and Journal of Enterprising Culture, among others.

Teemu Kautonen is a Professor in Entrepreneurship at the University of Vaasa, Finland and an Associate Member of the Centre for Knowledge, Innovation, Technology and Enterprise (KITE) at the University of Newcastle, UK. His current research focuses on trust in virtual environments, entrepreneurship and small business strategy and policy. Previous publications have appeared in the Journal of Small Business and Enterprise Development, International Entrepreneurship \& Management Journal, International Journal of Entrepreneurial Behaviour \& Research and Evolutionary and Institutional Economics Review, among others.

Heikki Karjaluoto is a Professor in Marketing at the University of Jyväskylä, Finland. His research interests include electronic business in general and mobile business and commerce in particular. Previous publications have appeared in the International Journal of Bank Marketing, Internet Research, International Journal of Retail \& Distribution Management, International Journal of Mobile Marketing, Journal of Services Marketing, Online Information Review, among others. 


\title{
Antecedents to permission based mobile marketing: An initial examination
}

\begin{abstract}
Purpose - A conceptual model is developed to examine the influence of four antecedent factors (personal trust, institutional trust, perceived control and experience) on consumers' willingness to participate in permission-based mobile marketing. We empirically test our model across three European countries and gender.
\end{abstract}

Methodology/approach - Data is collected from surveys of consumers in Finland, Germany and the UK. The Partial Least Squares (PLS) approach is utilised to test the model fit.

Findings - The main factor affecting the consumers' decision to participate in mobile marketing is institutional trust, which is a significant factor in all three countries and across gender. The influence of other antecedent factors are less pronounced. On the whole, we find that the more experienced consumers become with mobile marketing, the less influence of perceived control will have on permission. There are notable variations across gender, with perceived control being an important determinant of permission for men, while it is not so for women.

Research implications/limitations - The results indicate the relative importance of four antecedents in the likelihood of consumers giving their permission to companies to send mobile marketing messages.

Practical implications - As institutional trust is the most important determinant of permission based mobile marketing, mobile marketers should focus on building a strong and positive media presence and image, and thereby influence consumers' likelihood of giving permission to mobile based marketing.

Originality/value - The first international empirical investigation of the different antecedents of permission based mobile marketing.

Keywords: Institutional trust, personal trust, perceived control, mobile marketing, permission, Europe 


\section{Antecedents to permission based mobile marketing: An initial examination}

\section{Introduction}

It is perhaps not an exaggeration to assert that the mobile phone is the most ubiquitous personal item in the world. Over the years, the mobile phone has become an increasingly attractive product with added features. A corollary to this has been the rate of adoption, which has been very rapid with around 2.5 billion mobile phone subscribers globally (GSM Association, 2007), with penetration approaching 95 per cent in the European Union area. In some EU countries penetration has exceeded 100 per cent (European Electronic Communications Regulation and Markets Report, 2006). While the primary function of a mobile phone is to enable users to talk to each other, mobile phone services such as short messaging services (SMS, or text messaging in vernacular) have lately grown very rapidly. The widespread use of other forms of mobile services such as multimedia messaging, browsing the Web, the use of downloadable solutions such as java, mobile e-mail, mobile TV, and other services like navigation and video calls are in their infancy in many markets, but nevertheless gaining in prominence. Against this backdrop, organizations are increasingly appreciating the importance of mobile phones in marketing applications. Practitioners and academics alike argue that SMS will turn into an active direct marketing medium as part of the promotion mix. From a marketer's perspective, the benefits of mobile marketing include a high rate of personalisation, interactivity, and a low cost of reaching large target audiences at the right time and in the right place (e.g. Anckar and D'Incau, 2002; Facchetti et al., 2005). Therefore, mobile marketing is a very important tool for all marketers, for the simple reason that the combined benefits of mobile marketing are simply not yet available through any other medium. 
In many countries mobile marketing is subject to government regulation, which dictates that prior permission from the customer has to be sought before a mobile marketing message can be sent (Barwise and Strong, 2002; Barnes and Scornavacca, 2004; Leppäniemi and Karjaluoto, 2005). Additionally, mobile marketing also requires the customer to provide personal data to the marketer, so that the full benefits of mobile marketing can be put into use. Such personal data may include demographic and location information. The more companies can utilise various kinds of customer data, the more personalised, relevant and effective their mobile marketing is likely to be (Ho and Kwok, 2003; Yunos et al., 2003). Given this background, a question arises: how do organizations gain permission from consumers so that the mobile marketing can become an effective marketing tool? More specifically, what are the factors that influence consumers to subscribe to permission based mobile marketing? Given that this is a relatively new phenomenon, there is a dearth of studies examining permission based mobile marketing.

The objective of this study is to attempt to fill this research gap by developing and testing a model of the antecedents of permission based mobile marketing. We validate our inquiry through a cross national empirical study and test the conceptual model using consumer responses from three countries: Finland, Germany and the UK. A cross cultural study of this nature is both timely and important. It will give us an opportunity to examine as to whether cultural differences are reflected through differences in permission based marketing. We also examine the influence of these antecedents across gender. An understanding of the antecedents of mobile marketing permission would enhance our understanding of consumer behaviour in the mobile world. Moreover, it is very likely that successful mobile marketing campaigns will be a precursor to mobile shopping. Therefore, our inquiry would also be useful in understanding shopping behaviours in the mobile medium. 
From a practitioner's viewpoint, an understanding of the antecedents to permission is important, because the starting point for real two-way mobile communications between the customer and the marketer requires the customer to opt-in to the marketing program, in other words to give his or her permission to be included in the mobile marketing database. As most European mobile operators operate across different countries, the findings of our crosscultural study would be most beneficial. In line with the new EU regulation, permissions are never permanent and should thus always include a mechanism to opt-out. Therefore, knowledge of the factors that contribute to the customers' willingness to give permission is vital for effective mobile marketing campaigns.

The paper is arranged as follows. The next section presents the conceptual development. The methodology used is then described, followed by the study's results. Discussion of findings and implications for the mobile sector is then provided. The concluding section summarises the findings in light of the study's limitations, and provides potential future research avenues.

\section{Conceptual framework}

At the outset, it is useful to define mobile marketing. In this paper, we adopt the Mobile Marketing Association's definition: mobile marketing as the use of wireless media (primarily cellular phones and PDAs) as an integrated content delivery and direct response vehicle within a cross-media marketing communications program (MMA, 2006). According to Greenville (2005), one of the main reasons explaining the slow uptake of mobile marketing is the perceived lack of consumer trust. Greenville's study found that companies are reluctant to adopt mobile marketing mostly because they fear that the consumers are reluctant to participate, since the consumers are expected to worry about the problems of e-mail spamming being repeated on their mobiles. Another concern from the consumer perspective is how companies handle and use their personal information, which previous studies have found 
to be an issue in the context of Internet sites (Hoffman et al., 1999) and it is conceivable that similar concerns may exist in the context of mobile marketing (see also Yousafzai et al., 2003). Based on this literature, we chose personal and institutional trust as two potential antecedents of permission. This study adopts a broad "embedded" approach to analysing trust and its sources. This approach has been developed in recent literature to address not only the sources of trust which are internal to the relationship between individuals and/or organisations, but also factors in the surrounding legal, social and cultural environment that affect the emergence and development of trust (e.g. Bachmann, 2001; Kautonen and Kohtamäki, 2006; Zucker, 1986). Since the roles of these two sources of trust are likely to vary across countries due to differences in their legal, political and cultural frameworks (Bachmann, 2001; Doney et al., 1998; Järvenpää and Tractinsky, 1999; North, 1990), we chose a cross-country approach to testing the conceptual model in order to develop more robust concepts to describe the antecedents of permission. Customer's control over the number and type of mobile messages and the continuation/discontinuation of the mobile service was added into the model as a potential substitute for trust (Blomqvist et al., 2005; Nooteboom, 2002). For example, if the marketer offers an opt-out option the customer may feel in control of the mobile service, and thus perceive less risk in providing permission. The lesser risk, on the other hand, means that less trust is required to permit mobile marketing.

The model (shown in Figure 1) postulates that four variables (personal trust, institutional trust, experience in mobile marketing service products and perceived control) are direct antecedents of permission. The conceptual foundations in the model are offered next. For these links, specific conceptual evidence is not clear enough to warrant formal hypothesis. Therefore, we defer from offering formal hypothesis and provide preliminary conceptual evidence. 
<Take in Figure 1 about here>

\section{Permission}

Permission is the commencement of two-way mobile communications between the customer and the mobile marketer. In other words, permission can be understood as the "dynamic boundary produced by the combination of one's personal preferences" (Barnes and Scornavacca, 2004, p.133). These preferences include, for example personalisation of messages in terms of time, location and information content. As alluded to earlier, in Europe, marketers are required to seek consumer consent to be a part of any mobile marketing program. In short, without the explicit permission from the customer it is not possible to carry out mobile marketing. Seeking a customer's prior permission to send marketing messages via electronic channels such as mobile is called opt-in mobile marketing. It should be noted here that in the context of an existing customer relationship, mobile marketers are allowed to promote similar products or services to their opt-in customers under the opt-out rule, which refers to the customer's ability to opt-out of the communication in an immediate and easy manner (Leppäniemi and Karjaluoto, 2005).

\section{Personal trust}

Personal trust emerges either in personal interaction with the trustee (in this case the company to which the permission for mobile marketing should be granted) or via information about the trustee's past behaviour received from personally known sources (Yamagishi and Yamagishi, 1994; Sztompka, 1999; Kautonen and Kohtamäki, 2006). Thus, personal trust is composed of two components. The first component is concerned with the customer's relationship with the company that uses mobile marketing. This relationship would be a reflection of cumulative experiences with the company's products and services or encounters with the company's service personnel. This relationship shapes the customer's perception of the company's 
products and services, including its perceived trustworthiness. Personal trust can also be affected by social influence. This is based on the experiences that friends, family members, colleagues or other acquaintances in the customer's social network have had with the company, which they pass on to the customer in form of recommendations and narratives (Sztompka, 1999; Bauer et al., 2005; Welter and Kautonen, 2005). Thus, the second component of personal trust refers to social influence experienced by the customer from individuals in his or her social network. We argue that where individuals have positive perceptions of personal trust, they are more likely to give permission.

\section{Institutional trust}

Institutional trust, on the other hand, refers to the wider trust that the consumer has on the institutional environment, including legal, cultural and political institutions, civil societal organisations such as clubs and associations, and the media (Zucker, 1986; North, 1990; Raiser, 1999; Sztompka, 1999). In the context of permission based mobile marketing, we argue that institutional trust is a reflection of the media perception of the mobile organisation in question and institutional regulation. Individuals have limited access to information via personal interaction and social networks, which is why they rely on news reporting and advertising presented in the media (Shapiro, 1987). Thus, we propose that the company's media presence affects the way the consumer perceives the trustworthiness of the company in general (Schoenbachler and Gordon, 2002), and the trustworthiness of its mobile marketing communications in particular. For example, continuous advertising and a general presence in major media communicates the stability of the company and increases the consumer's familiarity with the company and its products, thereby contributing towards a source of trust (see e.g. Spence, 2002; Sztompka, 1999). The results of Li and Miniard's (2006) experimental study indicated that advertising enhanced a brand's perceived trustworthiness - even if the 
advertisements did not contain any overt trust claims. However, it also must be appreciated that on occasion media exposure can result in negative publicity, and thereby perhaps erode institutional trust to an extent.

The sources of institutional regulation that provide safeguards against the misuse of customer information include national governments, the EU and trade associations such as the Mobile Marketing Association. For example, the European Union approved a new directive (Directive/58/EC) which established standards for the processing of personal data and the protection of privacy in the electronic communications sector (European Union, 2002). On the one hand, the formal components of the institutional framework - in particular legal norms, regulations and their enforcement - must support the emergence and maintenance of trust (North, 1990). On the other hand, formal institutions alone are insufficient, but they must be supported and complemented by appropriate informal institutions. In this context, Welter and Smallbone (2003, p. 98) argue that informal institutions are "a culture-specific interpretation of formal rules". We argue that where institutionally based trust is present, consumers will have a positive perception towards permission based mobile marketing.

\section{Experience of mobile marketing}

That experience influences the consumer decision making process is well accepted in marketing literature. Prior experience of customers influences purchase and consumption (Foxall, 2003). In terms of understanding consumer behaviour in mobile settings, an influential example is the environmental response inventory (ERI). This describes “customers' openness to environmental experience, stimulation and distraction, urban and pastoral preferences, and adaptiveness" (Grossbart et al., 1990, p. 225). The ERI can be employed to assess interactions between consumers and the environment, such as the mobile marketing environment. This is appealing because it offers a ready formula for understanding 
consumer behaviour with respect to permission based mobile marketing. It can be argued that, since mobile marketing is a relatively new activity for a vast majority of consumers, it may be perceived to be riskier, and therefore consumers rely heavily on their experience. Experience can be acquired only through exposure to mobile marketing products and services. Consumers who have never bought or used mobile marketing products and services are more risk-averse than those who have bought before or used before (Foxall, 2002; 2003). That is, if a person uses mobile products and services regularly, it can be assumed he or she is more willing to provide permission

\section{Perceived control}

In general, perceived behavioural control (PBC) refers to people's perceptions of their ability to perform a given behaviour. Perceived behavioural control was added to the Theory of Reasoned Action in an attempt to deal with situations in which "people lack complete volitional control over the behaviour of interest" (Ajzen 2002, p. 2). As highlighted out by Ajzen (2002), although PBC is suggested to be measured indirectly in the same way as attitude and subjective norm, that is using belief based measures that capture also the cognitive foundations underlying perceptions of behavioural control, most studies have used direct measures in measuring $\mathrm{PBC}$ such as direct questions related to the three to five controlling factors that relate to the behavioural intention in question. Perceived behavioural control or a concept very similar to it called self-efficacy has been used as part of technology acceptance studies to predict intention to use (Mathieson, 1991; Taylor and Todd, 1995). While literature on the association of PBC and intention in mobile context is fresh, and there is no commonly accepted agreement whether and how perceived behavioural control affects intention to receive mobile marketing communications, a body of literature is emerging with preliminary results that suggest that perceived control has little or no association with 
intention to receive mobile marketing communications (Karjaluoto and Alatalo, 2007; Merisavo et al., 2007).

On the other hand, perceived control is found to play a significant role as a substitute or complement to trust in the context of business relations in form of contractual arrangements and self-enforcing safeguards (e.g. Blomqvist et al., 2005; Dyer, 1997; Nooteboom, 2002). In the mobile context, we postulate that control is mainly a substitute for trust analogue to the conceptualisations of the "bet of trust" in the literature (Gambetta, 1988; Kautonen and Kohtamäki, 2006; Sztompka, 1999). Here, the trustor perceives a certain degree of risk which needs to be covered before a transaction becomes feasible. Trust and control are commonly argued to be the mechanisms to cope with this risk. The substitution logic predicts that if more of one of these mechanisms is available, the less of the other is required for the transaction to take place (Nooteboom, 2002). Thus in the mobile context, the higher the perceived control, the less trust is required to permit mobile marketing. However, control may also complement trust. In the context of business relationships, a formal contract has been found to form a basis for subsequent trust-building (Klein Woolthuis et al., 2002). In the mobile context, if the marketer offers an opt-out option the customer may interpret this as a preliminary signal of trustworthiness and may actually develop personal trust more quickly than without the control mechanism in place.

Similarly, research in new technologies contends that the "many-to-many" (Gilmore and Pine, 1998; Hoffman and Novak, 1996) characteristic of new technologies attracts consumers with the promise of a bespoke service where the consumers perceive that they are in control. It is argued that the feeling of lack of perceived control may be a factor preventing consumers from participating in marketing in new media (Hoffman et al., 1999). If consumers perceive that they have control over the number and type of mobile messages that they receive, it is 
conceivable, that consumers would be more willing to give permission. Therefore we expect consumer's perceived control to have a positive influence on permission.

\section{The role of gender}

It has been argued that men and women differ in relation to how they process information, how they process environmental cues, and their needs in the purchase encounter (Minahan and Beverland, 2005). Previous work has identified differences in shopping-related attitudes based upon biological gender (Palan, 2002) and gender roles (Lavin, 1993), although distinct gender roles appear to have become somewhat blurred as evidenced by more recent work (Otnes and McGrath, 2001). For the purposes of this paper, gender is used to refer to biological gender.

Gender related work on permission based marketing is in its infancy. As explained earlier, mobile marketing could be a precursor to mobile retailing. Therefore, we have drawn from traditional retailing literature to conceptualise our arguments on how gender roles will have an influence on permission. Indeed, recent research in retailing has begun to present typologies of the respective shopping styles of men and women (Bakewell and Mitchell, 2004; Campbell, 1997; Dholakia and Chiang, 2003; Miller, 1998; Otnes and McGrath, 2001). However, despite this work, there remains a need for further research examining differences across gender (Otnes and McGrath, 2001). What authors have found thus far is that for most shopping experiences females are generally characterised by: imagining and envisioning the merchandise in use (Campbell, 1997); weighing up of the pros and cons of the purchase (Laroche et al.,, 2000); taking pride in their ability to shop (Underhill, 1999); viewing the shopping process as a leisure activity (Bakewell and Mitchell, 2004); spending longer shopping than men (Campbell, 1997); visiting more shops than men and shopping more often than men (Dholakia, 1999); including social interaction as an important part of the shopping 
experience (Otnes and McGrath, 2001); including entertainment in the shopping experience (Haytko and Baker, 2004); and shopping to express love for families and social networks (Miller, 1998). Men, on the other hand, generally have their shopping decisions characterised by the following: incisiveness, decisiveness, determination, and excitement at the 'moment of the kill' or purchase (Dennis et al., 2005); instrumentality and product specificity (Campbell, 1997); lack of patience and trying to complete the shopping activity in the shortest possible time (Bakewell and Mitchell, 2004); preference for top brands as both symbols of economic power (Underhill, 1999) and time savers (Bakewell and Mitchell, 2004); and shopping for power and achievement, so called 'shopping to win' (Otnes and McGrath, 2001).

Although the impact of demographics on mobile marketing acceptance and use is scarce, several studies have investigated the link between demographics including gender and mobile service usage (Karjaluoto et al., 2006; Nysveen et al., 2005a; 2005b; Pedersen, 2005). In terms of gender, studies have found that females are using more SMS services such as texting to others than males are (Karjaluoto et al., 2006; Pedersen, 2005). One possible reason for this is that females seem to value enjoyment, fun and the social dimensions related to mobile service usage (Nysveen et al., 2005b). In a series of Finnish surveys on mobile service usage, female respondents were found more active in ordering mobile services such as logos and ringtones, and in participating in mobile marketing in terms of sweepstakes and TV shows (Hyvönen and Repo, 2005; Karjaluoto et al., 2006). In a recent survey $(\mathrm{n}=4,062)$ Karjaluoto et al., (2006) also found that although females are more active in pull type of mobile marketing such as in participating in sweepstakes and TV programs, no differences in gender were found in push based mobile marketing referring to the number of mobile marketing messages received on mobile phone. Similarly, Okazaki (2004) found no relationship between gender and consumers' attitude toward mobile advertisements displayed on mobile websites. 
The above commentary implies that women, if they have had experience in mobile marketing products and services, or have experience in mobile shopping and enjoyed the experience, are more likely to give permission to mobile marketing. On the other hand, men are characterised by a lack of patience and a desire to finish mobile based activities as soon as possible. Therefore, unlike women, men are less likely to give permission due to positive experiences of mobile marketing. More specifically we argue that the strength of the relationship between the customer's experience of mobile marketing and the likelihood of his or her giving permission will be greater for women than for men. The existing literature does not enable us to present propositions on how the influence of the other constructs in the model and their influence on permission differ between men and women.

\section{Measures and questionnaire design}

Measurement instrument item scales were adapted from previous studies. The sources of construct scales are displayed in Appendix 1 together with the item measures. While personal trust, institutional trust, and perceived control were measured through reflective measures, we measured experience of mobile marketing services through formative measures. In contrast to empirical work focusing on a single country, cross-national research faces several additional challenges, caused for instance by different cultural values, social systems, status symbols and literacy rates (Cavusgil, 1997). Therefore, researchers have to secure not only that the respondents of different nationalities within the overall sample are reasonably comparable, but also to ensure that all respondents perceive the survey instrument as similarly as possible. Given the cross-national nature of our study, particular care had to be taken in translating the measures used in the survey, in order to secure that all respondents from Finland, Germany, and the UK perceive the questionnaire in a similar manner. Based on the Finnish questionnaire, German and English versions were developed following the standard 
procedures recommended by Brislin et al. (1973) allowing the identification and elimination of perceived differences between the various versions of the questionnaire.

\section{Methodology}

The data collection for this study was carried out by means of a survey questionnaire in Finland, Germany and the UK. The national samples comprise of 200 respondents in Finland, 207 in Germany and 260 in the UK. The samples of all countries consist of university students. A largely student-based sample suits a study of mobile marketing very well: this particular demographic group is generally more familiar with mobile services and uses them more than the general population (Wilska, 2003; Enpocket, 2004; Karjaluoto et al., 2005). We thereby enhanced the possibility that we have similar respondents across the three countries that have experience from giving permission and personal information to mobile marketers. While the German and UK surveys used a paper version of the survey, the Finnish version was partly carried out as an Internet survey with the link to the web questionnaire distributed via email. Due to the fact that Internet access among Finnish students approaches $100 \%$ we do not expect the sample to be biased by the different data collection methods (Cobanoglu et al., 2001; Miller, 2001). The administrators of the survey in Germany and the UK estimated the share of international students in their respective samples to be less than five percent. The Finnish questionnaire could only be filled out by a person fluent in Finnish, which de facto excludes international students. Hence, all samples are representative of the institutional and cultural environments of their respective countries for young consumers.

\section{Sample characteristics}

The gender distribution of the overall sample shows that 54.7 percent are male respondents. Most respondents are between 18 and 25 years of age (86.2\%). German respondents are slightly older on average (68.8\% aged $21-25$ and $24.9 \%$ aged $26-35)$, reflecting the German 
education system where university students tend to be older than in Finland or the UK. Similarly, reflective of the education system, the majority of the UK sample consists of 18-20 year olds $(96.9 \%)$, while the majority of the Finnish respondents are in their early twenties. The gender distributions in the individual countries show a male majority in Germany and the UK (67.8\% and 54.9\%, respectively) and a female majority in Finland (59.0\%).

\section{Data analysis and results}

\section{Customer mobile marketing experience - an overview}

With respect to the respondents' experience of mobile marketing, approximately 60 percent of the overall sample had received at least one marketing text message during the last month (the month prior to data collection), and around 9 percent had received more than five marketing text messages. Additionally, close to 30 percent reported having received at least one marketing text message in the previous month from a source whom they could not remember having given permission. In terms of participating in mobile marketing, around 30 percent had requested (more than once) information such as phone numbers, news, weather forecasts, or sports news by text message during the last six months. A total of 22 percent reported having ordered ring tones, screen savers or logos during the last month. Less than 10 percent had responded to a mobile marketing message by replying to the message (e.g. ordering a product or service or requested more information) during the last six months. Close to 13 percent had responded to a mobile marketing message either by visiting a website or calling the company. Around 20 percent of the respondents reported having participated in a lottery, TV program or having voted by using SMS. Table 1 shows the respondents' experience of mobile services and compares the respondents across the three countries.

<Take in Table 1 about here> 
Table 1 displays statistically significant differences at the $p<0.01$ level in all measures except in how many SMS/MMS marketing messages respondents had received last month. It appears that consumers in the UK receive more unsolicited mobile marketing messages compared to other groups. Interestingly, the Finnish respondents have requested over three times more often information over the mobile, such as phone numbers, news, weather forecasts, or sports news compared to the UK respondents, and over 16 times more often than the German respondents. Similarly, the Finnish respondents have been the most active in ordering mobile services such as ring tones, logos, and screen savers. It is also seen that the Finnish respondents have responded most positively to SMS marketing either by replying to the message directly, visiting a website or calling the company. They have also participated in TV programs and sweepstakes by using text messages more actively compared to German or UK respondents. Hence, it seems that young Finns are more acquainted with mobile services and use them more actively compared to young consumers in Germany and the UK.

\section{The conceptual model}

Data is analyzed by means of the Partial Least Squares (PLS) approach (Wold, 1985; Chin, 1998), utilizing the software package SmartPLS (Ringle et al., 2005) While other methods of structural equation modelling (SEM) - such as the covariance-based LISREL - are more widespread indeed, we decided in favour of the PLS approach due to its enhanced ability to process formative constructs in SEM analyses. The data analysis process involved two main steps. First, we tested our conceptual model on the combined data for all three countries represented in the sample. Second, an exploratory group comparison (Chin, 2000) was conducted in order to discover differences between the antecedents of permission for mobile marketing in the three respective countries. Furthermore, gender differences between male and female consumers were explored. 


\section{Confirmative results - Assessment of measurement models}

The model consists of two second-order-reflective-constructs (Wold, 1982), i.e. institutional trust and personal trust, two first-order-reflective constructs, i.e. perceived control and permission, and one first-order-formative construct, i.e. experience of mobile marketing services. For all reflective constructs, all item measures show loadings of more than 0.7 so that no item measure has to be deleted. Construct reliability (see Table 2) is assessed by calculating Cronbach's $\alpha$, Composite Reliability and Average Variance Extracted (AVE). All constructs, both in the combined data and the different subsamples show satisfying levels that are in line with the usual threshold values (Chin, 1998). However, perceived control in the Finnish data is slightly below the recommend threshold of 0.7 for Cronbach's $\alpha$ (Nunnally, 1978), however, no changes were carried out to secure comparability between the other different subsamples. Moreover, the composite reliability score for this particular construct exceeds the recommended threshold, indicating that there is indeed sufficient reliability on the construct level despite a relatively weak $\alpha$-score.

<Take in Table 2 about here>

Discriminant validity is assessed both at the item level and at the construct level. With respect to item discriminant validity, an inspection of indicator cross-loadings reveals that all indicators are loading at their highest with their respective construct and that no indicator loads higher on other constructs than on its intended construct. It is therefore safe to assume item discriminant validity. At the construct level, the comparison of each reflective construct's AVE and the squared latent variable correlations (Chin, 1998) suggests that there is indeed satisfactory discriminant validity (Cool et al., 1989). Table 3 presents the very favourable results of this test for the combined data; a sub-sample analysis revealed that there is equally sufficient discriminant validity for each construct in every sub-sample. 
<Take in Table 3 about here>

As stated earlier, experience with mobile marketing was operationalized with formative measures (Jarvis et al., 2003; Diamantopoulos and Winklhofer, 2001). Tests for multicollinearity of the indicators suggest that no indicator has to be eliminated due to nonexistent multicollinearity. Overall, the evaluation of the reflective and formative measurement models reveals that all constructs are of satisfactory reliability and validity.

\section{Assessment of the inner model}

All structural equation models are calculated with four exogenous variables $\xi 1$ to $\xi 4$ and one endogenous variable $\eta$, permission. In order to estimate paths between the latent variable, the path weighting scheme is utilized, being the only weighting scheme that explicitly considers the conceptual model directions of the causal relationships between exogenous and endogenous variables (Chin, 1998; Lohmöller, 1989). Following common conventions, the abort criterion for the iterative estimation process is selected as a change of the estimated values of just $10^{-5}$ percent between two iterations. In order to determine the significance of each estimated path, a standard bootstrapping procedure (Yung and Bentler, 1996) was applied with 500 resamples consisting of the same number of cases as in the original sample. Potential sign changes during the course of the resampling are treated by means of the option "individual sign changes". Figure 2 depicts the resulting path model for the combined three country data set and five exploratory models.

$<$ Take in Figure 2 about here>

Results show that the general model explains a satisfying amount of the endogenous variable's variance $\left(\mathrm{R}^{2}=0.397\right)$, indicating an acceptable explanatory power of the model. Moreover, the Stone-Geisser-Criterion points towards the interpretation, that the model is of 
satisfying predictive relevance $\left(Q^{2}=0.319\right)$. Therefore, an interpretation of the conceptual model's causal relationships is possible. Overall, data and analysis support all conceptualised model relationships. While personal trust, mobile marketing experience and perceived control reveal a similar influence on the permission for mobile marketing, our data suggests that institutional trust plays the most significant role in influencing permission for mobile marketing. Consequently, the results of the PLS-analysis support our theoretical reasoning quite well.

\section{Exploratory results}

While trust theory together with the emerging literature on mobile marketing allows us to conceptualise the antecedents of permission-based mobile marketing, it is not prudent to generalise these relationships in a global context. We therefore report results of an explorative analysis that compared different sub-samples in our data for gender differences and country differences by means of a group comparison. We followed recommendations set forth by Chin (2000) while conducting the group comparison (for other studies using similar approaches see Avolio et al., 1999 or Keil et al., 2000). Separate models were estimated for each subsample resulting in five new models (shown in Figure 2), i.e. a male model of the combined data, a female model of the combined data and three country specific models for Finland, UK, and Germany (see Tables 4 and 5). All models are of sufficient explanatory power and predictive relevance as indicated by their respective $\mathrm{R}^{2}$ and $\mathrm{Q}^{2}$ values.

\section{$<$ Take in table 4 about here>}

Comparing the male model to the general combined data model reveals a very similar picture. Institutional trust influences permission for mobile marketing the most, while the other antecedents are less influential, as it is the case with the general model. The inspection of the female model, however, reveals significant differences - female consumers appear to base 
their decision to allow to give permission primarily on institutional trust and their prior experience with mobile marketing campaigns. Personal trust and perceived control do not appear to have an influence on permission for mobile marketing with female consumers. Additionally, with respect to female consumers, institutional trust plays an even more decisive role - we find a significant difference in path coefficients of male and female consumers $(\Delta$ $0.184 ; \mathrm{p} \leq 0.05)$

In keeping with the general model findings, country wide examination confirmed that for consumers in all three countries, institutional trust is by far the most important factor in influencing permission. Nevertheless, significant differences can be observed in relation to the remaining antecedents across the three countries (see Table 5). For German consumers perceived control appears to exert a strong influence on the permission for mobile marketing; perhaps this is an indication of their relatively less experience with mobile marketing. Conversely, when examining more mobile-mature markets, such as the Finnish market, perceived control appears to become irrelevant. Finnish consumers decide upon the permission for mobile marketing primarily by relying on both personal and institutional trust along with their experience of mobile marketing. On the other hand, results for the British market show that personal trust exerts no influence on permission; more specifically, British consumers appear to rely on institutional trust, their personal experience with mobile marketing and control as significant influences on permission. Additionally, we strengthened our findings by comparing the differences in the respective path coefficients between the countries - findings suggest significant variations on how control options are perceived in Finland compared to Germany $(\Delta 0.305 ; \mathrm{p} \leq 0.001)$ and the UK $(\Delta 0.188 ; \mathrm{p} \leq 0.01)$, and there are significant variations of the role of personal trust in the UK compared to Germany ( $\Delta$ $0.240 ; \mathrm{p} \leq 0.01)$ and Finland $(\Delta 0.224 ; \mathrm{p} \leq 0.01)$. 


\section{Discussion}

The conceptual model in this study postulated that personal trust, institutional trust, perceived control and experience of mobile marketing services are antecedents of permission. Of the two dimensions of trust, i.e. personal and intuitional trust, we find that institutional trust is the most important antecedent of mobile marketing permission. The dominant influence of institutional trust is also equally evident at individual county level. Previous studies that have examined how consumers evaluate the trustworthiness of service providers indicate that factors such as reputation or brand name are important (e.g. Cho, 2006; Li and Miniard, 2006). These researchers conclude that these factors are important, particularly at the inception of a relationship. Perhaps, this indicates the very nature of the "mobile marketing"" industry. It is an industry that is very much in its infancy. Therefore, it is logical that customers make their decisions based on their perception of the organisation. This supports Li and Miniard's (2006) findings that advertising increases a brand's trustworthiness even if the advertising does not aim to do this specifically. A methodological issue might also have influenced the results of this study. Institutionally based trust in general is largely routinebased tacit knowledge (Kautonen and Kohtamäki, 2006), and thus it is difficult to measure reliably. Hence, it is possible that the respondents "do not know" that certain legal and cultural rules and norms affect their behaviour and the role of institutionally based trust thus appears to be the more "tangible" form of media presence, the measures of which are perhaps more related to explicit knowledge. This is a challenge that needs to be addressed carefully in future operationalisations of institutionally based trust.

While personal trust is significant in the overall sample, it is not a significant antecedent of permission in the UK. This finding is in contrast to previous research (e.g. Lewis and Weigert, 1985; Sztompka, 1999; Welter and Kautonen, 2005), which tends to attribute personal experiences - and the personal trust category as a whole, including social influence - 
a more important role than institutionally based trust. A possible explanation can be found by applying the concept of experience accumulation. In the context of relationships, a strong determinant of trust is the length and depth of the relationship, or how well the partner is known (Kramer, 1999; Sztompka, 1999; Yamagishi and Yamagishi, 1994). It is possible that a consumer perceives to "know" the media better than individual companies, and thus assigns more value to the company's appearance in the media - and media as a source of trust - than experiences with the company as such, even if the media presence takes the form of advertisements.

While perceived control is found to play a significant role in the context of business relations in form of contractual arrangements and self-enforcing safeguards (e.g. Blomqvist et al., 2005; Dyer, 1997), its role in our model is modest. This is in keeping with emerging mobile marketing literature that suggest that perceived control has little or no association with intention to receive mobile marketing communications (Karjaluoto and Alatalo, 2007; Merisavo et al., 2007). However, it is possible that trust may be a pre-requisite for control (see e.g. Nooteboom, 2002 for a related discussion in the context of business relations). That is, if customers do not trust the company, then they do not trust the company's promise to allow them to "control" the permission in the first place. In our examination of cross country samples, we found that the influence of control varies from country to country. Although the Finnish sample did not indicate that perceived control has an influence on permission, both the German and UK samples indicate a significant influence of control on permission. Two possible explanations can be presented. One is based on the general level of trust (both personal and institutional) in a country, which diminishes the need for control. The results of the 2006 World Values Survey (WVSA, 2006) indicate that Finland has a particularly high level of such general trust, which could explain the absence of control in the Finnish results. Another possible explanation reflects the particular characteristics of the samples. Finnish 
consumers are more acquainted and experienced with mobile services and use them more actively than their British or German counterparts. If mobile services are well-known, actively used, and consumers are experienced, they have a high legitimacy which might lessen the need for control. Additionally, consumers in the UK are more likely to receive unsolicited mobile marketing messages than the other groups. Somewhat understandably, UK consumers therefore expressed the strongest desire to have the most amount of control over their ability to give personal information to and permission to companies. At the opposite end, Finnish consumers who reported to have received the least amount of unsolicited messages, we observe that control is not a significant predicator of mobile marketing permission. We appear to have validated an intuitive proposition: there appears to be an inverse relationship between experience in mobile marketing and perceived control. In other words, the more experienced consumers become with mobile marketing, the less influence perceived control will have on permission. Consumers are quite keen to ensure that companies should only use personal information when explicit permission is given by the owner of the information. It could be concluded that mobile marketing campaigns are probably less likely to succeed and will be negatively perceived, if consumers' permission is not sought.

We postulated that with respect to gender roles, the strength of the relationship between the customer's experience of mobile marketing and the likelihood of his or her giving permission will be greater for women than for men. The data does not support our proposition. We find that both sexes have similar dispositions towards permission. We do, however, find that both for men and women, institutional trust is a significant predictor of permission. However, perceived control is a significant influence on permission for men but not for women. There may in fact be perfectly logical reasons for this finding. Drawing on retailing literature, we assumed in our arguments that men, due to impatience when making mobile decisions, are unlikely to have as strong a relationship between experience of mobile marketing and 
permission. Given that men are shrewd and incisive when making shopping decisions (Dennis et al., 2005) their enjoyment of a mobile experience may be driven by their desire to fulfil certain of their experience expectations. Perhaps mobile marketing is a functional activity for men, allowing them to be decisive, hence their desire for greater perceived control.

\section{Conclusions and further research}

This study set out to conceptualise how trust, experience and perceived control affect the customer's willingness to provide companies with personal information and permission to use it in mobile marketing, to investigate cross-country differences in these influences, and examine gender differences. A conceptual model was developed based on a literature review, and it was subsequently tested with data from Finland, Germany and the UK. The main finding of the study is that the main factor affecting the consumers' decision to participate in mobile marketing is institutional trust, which is a significant factor in all three countries and with no gender differences. The influences of other antecedent factors are less pronounced. We find that the more experienced consumers become with mobile marketing, the less influence perceived control will have on permission. Moreover, perceived control is an important determinant of permission for men, while it is not so for women.

In terms of managerial implications, as the results indicate that as a company's presence (as signified by institutional trust) accounts more than the customer's own experiences, mobile marketers should focus on building a strong and positive media presence and image through advertising, and thereby gain consumers' trust. Moreover, the different results for different countries show that multinationals need to fit their mobile marketing campaigns to the respective environment. For example, including control options for the benefit of the customer and communicating their existence explicitly could increase the legitimacy of mobile marketing in Germany and the UK, but less so in Finland. 
The results of this study provide a foundation to the understanding of the antecedents of permission based mobile marketing. However, in considering any research, it is important to evaluate the limitation of the work. First, our sample is composed of predominantly young mobile consumers with $86.2 \%$ of them falling into the $18-25$ age group. While we acknowledge that that this is not representative sample of the general mobile user population, as cited in the methodology section, previous research in mobile marketing has found that this is the age group most likely to be familiar with mobile marketing. Second, we measured a limited number of variables in our work. It is conceivable that there may be additional factors that could contribute towards permission based mobile marketing. Future studies could explore such variables.

This study does, moreover, offer several directions for future research into the mobile user behaviour. It would be quite useful to replicate this study with a more representative sample of mobile users in another country. This would help to ascertain whether or not our findings would be replicated in other markets. Second, an interesting avenue for further research concerns the process perspective to trust. The results of this study indicate that a number of factors play a role in the formation of trust and, consequently, these influence the likelihood of consumers giving their permission to companies to send mobile marketing messages. However, the study of trust in the context of mobile marketing and indeed trust research more generally, would greatly benefit from studies that adopt an evolutionary perspective and address the process of how trust emerges, develops and possibly diminishes. Here, longitudinal research designs are required and qualitative approaches could provide a useful complement to surveys. Last but not least, it would also be quite useful to replicate this study in other countries in order to validate our findings. 


\section{Acknowledgements}

The financial support of the Finnish Funding Agency for Technology and Innovation is gratefully acknowledged. 


\section{References}

Ajzen, I. (2002), "Perceived behavioural control, self-efficacy, locus of control, and the Theory of Planned Behaviour", Journal of Applied Social Psychology, Vol. 32 No. 4, pp. 1-20.

Anckar, B. and D'Incau, D. (2002), “Value-added services in mobile commerce: an analytical framework and empirical findings from a national consumer Survey", Proceedings of the 35th Hawaii International Conference on System Sciences (HICSS-35), Hawaii, USA.

Avolio, B.J., Howell, J.M. and Sosik, J.J. (1999), "A funny thing happened on the way to the bottom line - Humour as a moderator of leadership style effects", Academy of Management Journal, Vol. 42 No. 2, pp. 219-27.

Bachmann, R. (2001), "Trust, power and control in trans-organizational relations", Organization Studies, Vol. 22 No. 1, pp. 337-65.

Bakewell, C. and Mitchell, V-W. (2004), "Male consumer decision-making styles", International Review of Retail, Distribution and Consumer Research, Vol. 14 No. 2, pp. 223-40.

Barnes, S. and Scornavacca, E. (2004), "Mobile marketing: the role of permission and acceptance", International Journal of Mobile Communications, Vol. 2 No. 2, pp. 12839.

Barwise, P. and Strong, C. (2002), "Permission-based mobile advertising", Journal of Interactive Marketing, Vol. 16 No. 1, pp. 14-24.

Bauer, H.H., Barnes, S.J., Reichardt, T. and Neumann, M.M. (2005), "Driving consumer acceptance of mobile marketing: a theoretical framework and empirical study", Journal of Electronic Commerce Research, Vol. 6 No. 3, pp. 181-92.

Blomqvist, K., Hurmelinna, P. and Seppänen, R. (2005), "Playing the collaboration game right: balancing trust and contracting”, Technovation, Vol. 25 No. 5, pp. 497-504.

Brislin, R., Lonner, W. and Thorndike, R. (1973), Cross-cultural Research Methods, John Wiley \& Sons, Chichester. 
Campbell, C. (1997), "Shopping, pleasure and the sex war", in Falk, P., Campbell, C. (Eds), The Shopping Experience, Sage, London, pp. 166-76.

Cavusgil, S.T. (1997), "Methodological issues in empirical cross-cultural research: a survey of the management literature and a framework", Management International Review, Vol. 37 No. 1, pp. 71-96.

Chin, W.W. (2000), "Frequently asked questions - partial least squares \& PLS-graph", http://disc-nt.cba.uh.edu/chin/plsfaq.htm [Accessed 27/03/2007]

Chin, W.W. (1998), "The partial least squares approach to structural equation modelling" in Marcoulides, G.A. (Ed.), Modern Methods in Business Research, Earlbaum, Hillsdale, pp. 295-336.

Cho, J. (2006), "The mechanism of trust and distrust formation and their relational outcomes", Journal of Retailing, Vol. 82 No. 1, pp. 25-35.

Cobanoglu, C., Warde, B. and Moreo, P.J. (2001), “A comparison of mail, fax and web-based survey methods", International Journal of Market Research, Vol. 43 No. 4, pp. 441-52.

Coleman, J.S. (1990), Foundations of Social Theory, Belknap Press, Cambridge, Mass.

Cool, K., Dierickx, I. and Jemison, D. (1989), "Business strategy, market structure and riskreturn relationships: A structural approach", Strategic Management Journal, Vol. 10 No. 6, pp. 507-22.

Dennis, C., Newman, A. and Marsland, D. (2005), Objects of Desire: Consumer Behaviour in Shopping Centre Choices, Palgrave MacMillan, Basingstoke.

Dholakia, R.R. (1999), “Going shopping: key determinants of shopping behaviours and motivations", International Journal of Retail and Distribution Management, Vol. 27 No. 4, pp. 154-65.

Dholakia, R.R. and Chiang, K-P. (2003), "Shoppers in cyberspace: Are they from Venus or Mars and does it matter?", Journal of Consumer Psychology, Vol. 13 No. 1/2, pp. 1716.

Diamantopoulos, A. and Winklhofer, H.M. (2001), "Index construction with formative indicators: An alternative to scale development”, Journal of Marketing Research, Vol. 38 No. 2, pp. 269-77. 
Doney, P.M., Cannon, J.P. and Mullen, M.R. (1998), "Understanding the influence of national culture on the development of trust", Academy of Management Review, Vol. 23 No. 3, pp. 601-20.

Dyer, J.H. (1997), "Effective interfirm collaboration: how firms minimize transaction costs and maximize transaction value", Strategic Management Journal, Vol. 18 No. 7, pp. $535-56$.

Enpocket (2004), Enpocket Mobile Media Monitor (UK), Research Report (February).

European Electronic Communications Regulation and Markets (2006), http://ec.europa.eu/information_society/policy/ecomm/implementation_ enforcement/annualreports/11threport/index_en.htm [Accessed 01/04/07]

European Union (2002), “2002/58/EC”, Official Journal at OJ L201/37, Vol. 31 No. 2, http:// europa.eu.int/information_society/topics/telecoms/regulatory/new_rf/index_en.htm [Accessed 17/04/2007]

Facchetti, A., Rangone, A., Renga, F.M. and Savoldelli, A. (2005), "Mobile marketing: an analysis of key success factors and the European value chain", International Journal of Management and Decision Making, Vol. 6 No. 1, pp. 65-80.

Foxall, G.R. (2002), Consumer Behaviour Analysis: Critical Perspectives, Routledge, London and New York.

Foxall, G.R. (2003), "The behaviour analysis of consumer choice: an introduction to the special issue", Journal of Economic Psychology, Vol. 24 No. 5, pp.581-88.

Gambetta, D. (1988), “Can we trust?”, in Gambetta, D. (Ed), Trust: Making and Breaking Cooperative Relations, Basil Blackwell, Oxford, pp. 213-37.

Gilmore, J.H and Pine II, J.H.(1998), “The four faces customization”, Harvard Business Review, January-February, pp. 91-101.

Granovetter, M. (1973) “The strength of weak ties,” American Journal of Sociology, Vol. 78 No. 6, pp. 1360-80.

Greenville, M. (2005), “Stats \& research: big brands still won't use mobile”, 160Characters, http://www.160characters.org/news.php?action=view\&nid=1647 [Accessed 26/10/06] 
Grossbart, S., Hampton, R., Rammohan, B. \& Lapidus, R. S. (1990), "Environmental dispositions and customer response to store atmospherics". Journal of Business Research, Vol. 21, pp. 225-41.

GSM Association, 2007, “GSM subscriber statistics”, Q2 2006, http://www.gsmworld.com/news/statistics/index.shtml [Accessed 01/01/07].

Haytko, D.L. and J. Baker (2004), "It's all at the mall: exploring adolescent girls' experiences", Journal of Retailing, Vol. 80 No. 1, pp. 67-83.

Ho, S.Y. and Kwok, S.H. (2003), "The attraction of personalized service for users in mobile commerce: an empirical study", ACM SIGecom Exchanges, Vol. 3 No 4, pp. 10-8.

Hoffman, D.L. and Novak, T.P. (1996), "Marketing in hypermedia computer-mediated environments: Conceptual foundations", Journal of Marketing, Vol. 60 No. 3, pp. 5068.

Hoffman, D.L., Novak, T.P. and Peralta, M. (1999), "Building consumer trust online", Communications of the ACM, Vol. 42 No. 4, pp. 80-85.

Hyvönen, K. and Repo, P. (2005), "Mobiilipalvelut suomalaisten arjessa [in English: Mobile services in Finnish consumers' everyday life]", in Leskinen, J., Hallman, H., lsoniemi, M. et al. (Eds), Vox Consumptoris -Kuluttajan Ä̈̈ni [in English: Consumer's Voice], The National Consumer Research Centre, Savio Publishers Ltd, Kerava, Finland, pp. 41-59.

Järvenpää, S.L. and Tractinsky, N. (1999), "Consumer trust in an Internet store: a crosscultural validation", Journal of Computer-Mediated Communication, Vol. 5 No. 2, http://jcmc.indiana.edu/vol5/issue2/jarvenpaa.html [Accessed 01/08/2006]

Jarvis, C.B., MacKenzie, S.B. and Podsakoff, P.M. (2003), “A critical review of construct indictors and measurement model misspecification in marketing and consumer research”, Journal of Consumer Research, Vol. 30 No. September, pp. 199-218.

Karjaluoto, H. and Alatalo, T. (2007), “Consumers' attitudes towards and intention to participate in mobile marketing", International Journal of Services Technology and Management, Vol. 8 No. 2/3, pp. 155-73.

Karjaluoto, H., Karvonen, J., Kesti, M., Koivumäki, T., Manninen, M., Pakola, J., Ristola, A. and Salo, J. (2005), "Factors affecting consumer choice of mobile phones: two studies from Finland", Journal of Euromarketing, Vol. 14 No. 3, pp. 59-82. 
Karjaluoto, H., Leppäniemi, Standing, C., Kajalo, S., Merisavo, M., Virtanen, V., and Salmenkivi, S. (2006), "Individual differences in the use of mobile services among Finnish consumers", International Journal of Mobile Marketing, Vol. 1 No. 2, pp. 4-10.

Kautonen, T. and Kohtamäki, M. (2006), "Endogenous and exogenous determinants of trust in inter-firm relations: a conceptual analysis based on institutional economics", Finnish Journal of Business Economics, Vol. 55 No. 3. pp. 6-21

Keil, M., Tan, B.C., Wei, K., Saarinen, T., Tuunainen, V. and Wassenaar, A. (2000), “A cross-cultural study on escalation of commitment behaviour in software projects", MIS Quarterly, Vol. 24 No. 2, pp. 299-324.

Klein Woolthuis, R., Hillebrand, B. and Nooteboom, B. (2002), "Trust and formal control in interorganizational relationships", Erasmus Research Institute in Management Report Series ERS-2002-13-ORG.

Kramer, R.M. (1999), “Trust and distrust in organizations: Emerging perspectives, enduring questions", Annual Review of Psychology, Vol. 50, pp. 569-98.

Laroche, M., Saad, G., Cleveland, M. and Browne, E. (2000), "Gender differences in information search strategies for a Christmas gift”, Journal of Consumer Marketing, Vol. 17 No. 6, pp. 500-24.

Lavin, M. (1993), "Husband-dominant, wife-dominant, joint: A shopping typology for baby boom couples", Journal of Consumer Research, Vol. 10 No. 3, pp. 33-42.

Leppäniemi, M. and Karjaluoto, H. (2005), "Factors influencing consumer willingness to accept mobile advertising: a conceptual model”, International Journal of Mobile Communications, Vol. 3 No. 3, pp. 197-213.

Lewis, J.D. and Weigert, A. (1985), “Trust as a social reality”, Social Forces, Vol. 63 No. June, pp. 967-85.

Li, F., and Miniard, P.W. (2006), "On the potential for advertising to facilitate trust in the advertised brand", Journal of Advertising, Vol. 35, pp. 101-12.

Lohmöller, J. (1989), Latent Variable Path Modelling with Partial Least Squares, PhysicaVerl, Heidelberg. 
Mathieson, (1991), "Predicting user intentions: Comparing the Technology Acceptance Model with the Theory of Planned Behaviour", Information Systems Research, Vol. 2 No. 3, pp. 173-91.

McKnight, D.H., Cummings, L.L. and Chervany, N.L. (1998), "Initial trust formation in new organizational relationships", Academy of Management Review, Vol. 23 No. 3, pp. 473 90.

Merisavo, M., Kajalo, S., Karjaluoto, H., Virtanen, V., Salmenkivi, S., Raulas, M. and Leppäniemi, M. (2007), “An empirical study of the drivers of consumer acceptance of mobile advertising”, Journal of Interactive Advertising, Vol. 7 No. 2 , http://www.jiad.org/index.htm

Miller, D. (1998), A Theory of Shopping, Cornell University, Ithaca, NY.

Miller, T.W. (2001), “Can we trust the data of online research?”, Marketing Research, Vol. 13 No. 2, pp. 26-32.

Minahan, S. and Beverland, M. (2005), Why Women Shop, Wrightbooks, Milton, Qld.

MMA -Mobile Marketing Association (2006), "MMA annual mobile marketing guide", http://mmaglobal.com/modules/article/view.article.php/685

Nooteboom, B. (2002), Trust: Forms, Foundations, Functions, Failures and Figures, Elgar, Cheltenham.

North, D.C. (1990), Institutions, Institutional Change and Economic Performance, Cambridge University Press, Cambridge.

Nunnally, J. (1978), Psychometric Theory, McGraw-Hill, New York.

Nysveen, H., Pedersen, P.E. and Thorbjornsen, H. (2005a), "Intentions to use mobile services: antecedents and cross-service comparisons", Journal of the Academy of Marketing Science, Vol. 33 No. 3, pp. 330-46.

Nysveen, H., Pedersen, P.E. and Thorbjornsen, H. (2005b), "Explaining intention to use mobile chat services: moderating effects of gender", Journal of Consumer Marketing, Vol. 22 No. 5, pp. 247-56.

Okazaki, S. (2004), "How do Japanese consumers perceive wireless ads? A multivariate analysis", International Journal of Advertising, Vol. 23 No. 4, pp. 429-54. 
Otnes, C. and McGrath, M.A. (2001), "Perceptions and realities of male shopping behaviour", Journal of Retailing, Vol. 77 No. 1, pp. 111-37.

Palan, K.M. (2002), “Gender identity in consumer behaviour research: A literature review and research agenda", Academy of Marketing Science Review, Vol. 20 No. 10, pp. 1-26.

Pedersen, P.E. (2005), “Adoption of mobile internet services: An exploratory study of mobile commerce early adopters", Journal of Organrzational Computing and Electronic Commerce, Vol. 15 No. 3, pp. 203-21.

Raiser, M. (1999), “Trust in transition”, European Bank for Reconstruction and Development Working Paper, No. 39.

Ringle, C., Wende, S. and Will, A. (2005), Smart-PLS Version 2.0 M2, available at http://www.smartpls.de.

Schoenbachler, D.D. and Gordon, G.L. (2002), “Trust and customer willingness to provide information in database-driven relationship marketing", Journal of Interactive Marketing, Vol. 16 No. 3, pp. 2-16.

Shapiro, S.P. (1987), "The social control of impersonal trust", American Journal of Sociology Vol. 93, pp. 623-58.

Spence, M. (2002), "Signaling in retrospect and the informational structure of markets", American Economic Review, Vol. 92 No. 3, pp. 434-59.

Sztompka, P. (1999), Trust: A Sociological Theory, Cambridge University Press, Cambridge.

Taylor, S. and Todd, P. (1995), “Assessing IT usage: The role of prior experience”, MIS Quarterly, Vol. 19 No. December, pp. 561-70.

Tsang, M.M., Ho, S. and Liang, T. (2004), "Consumer attitudes toward mobile advertising: an empirical study”, International Journal of Electronic Commerce, Vol. 8 No. 3, pp. 6578.

Underhill, P. (1999), Why We Buy, Orion, London.

Vogt, J. (1997), Vertrauen und Kontrolle in Transaktionen: Eine institutionenökonomische Analyse, Gabler, Wiesbaden. 
Welter, F. and Kautonen, T. (2005), “Trust, social networks and enterprise development: exploring evidence from East and West Germany", International Entrepreneurship \& Management Journal, Vol. 1 No. 3, pp. 367-79.

Welter, F. and Smallbone, D. (2003), "Entrepreneurship and enterprise strategies in transition economies: an institutional perspective", in Kirby, D., Watson, A. (Eds), Small Firms and Economic Development in Developed and Transition Economies: A Reader, Ashgate, Aldershot, pp. 95-114.

Wilska, T.-A. (2003), "Mobile phone use as part of young people's consumption styles", Journal of Consumer Policy, Vol. 26 No. 4, pp. 441-63.

Wold, H. (1982), "Soft modelling: the basic design and some extensions", in Jöreskog, K.G., Wold, H. (Eds), Systems Under Indirect Observations, North Holland Publications, Amsterdam, p. 1-52.

Wold, H. (1985), "Partial least squares", in Kotz, S., Johnson, N.L. (Eds), Encyclopaedia of Statistical Science, Wiley, New York, pp. 581-91.

World Values Survey [WVSA] (2006), www.worldvaluessurvey.org. [Accessed 05/08/06] Yamagishi, T. and Yamagishi, M. (1994), "Trust and commitment in the United States and Japan", Motivation and Emotion, Vol. 18 No. 2, pp. 129-66.

Yousafzai, S.Y. Pallister, J.G and Foxall, G.R. (2003), “A proposed model of e-trust for electronic banking", Technovation, Vol. 23 No. 11, pp. 847-60.

Yung, Y. and Bentler, P.M. (1996), "Bootstrapping techniques in analysis of mean and covariance structures", in Marcoulides, G.A., Schumacker, R.E. (Eds), Advanced Structural Equation Modelling. Issues and Techniques, Lawrence Erlbaum, Mahwah, New Jersey, pp. 195-226.

Yunos, H.M., Gao, J.Z. and Shim, S. (2003), "Wireless advertising's challenges and opportunities", IEEE Computer, Vol. 36 No. 5, pp. 30-7.

Zucker, L.G. (1986), "Production of trust: institutional sources of economic structure, 18401920”, Research in Organizational Behaviour, Vol. 8, pp. 53-111. 
Figure 1: Conceptual Model

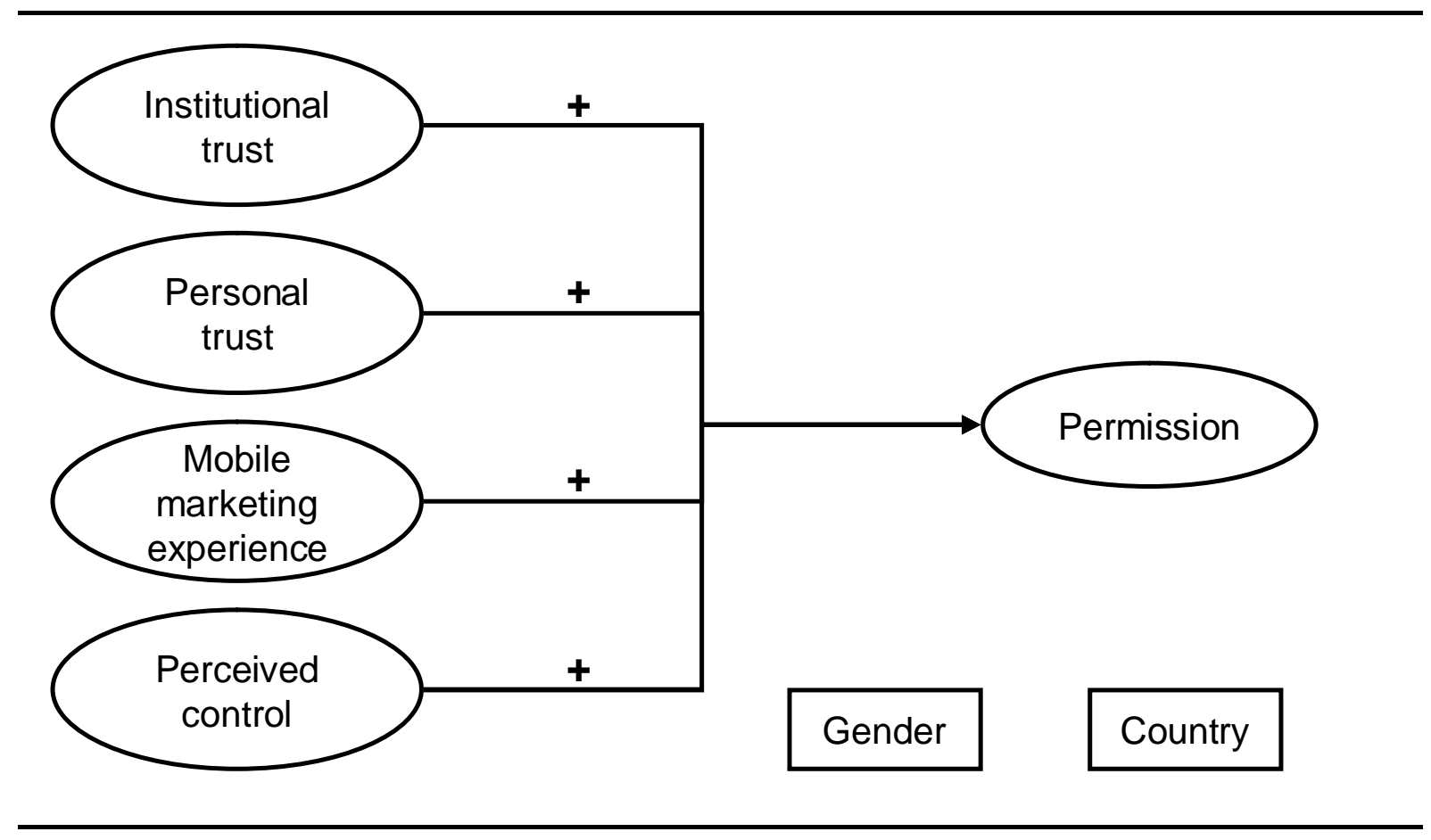


Figure 2: Results - partial least squares path models for combined / FIN / GER / UK / male / female data

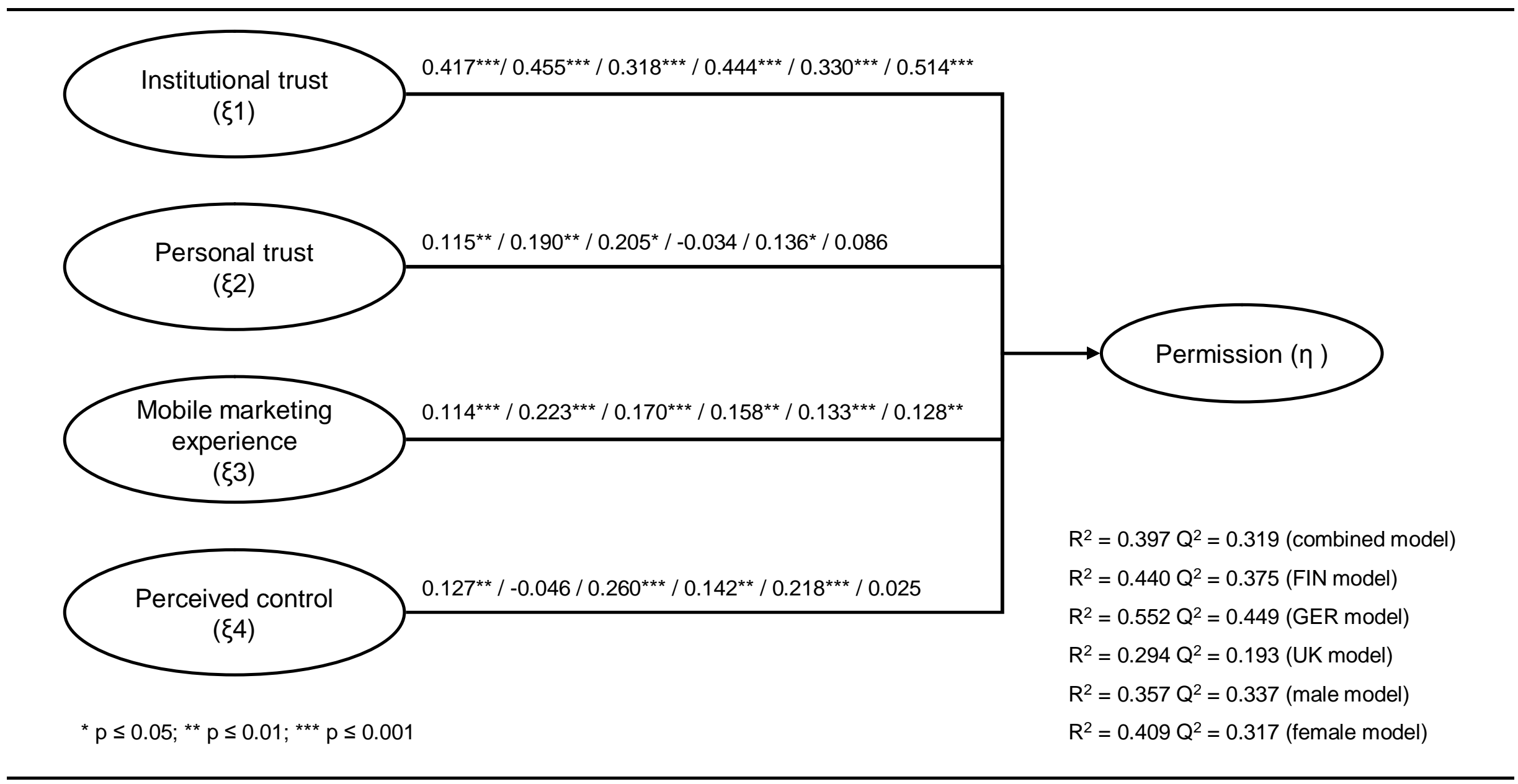


Table 1: Experience of mobile services

\begin{tabular}{lrr}
\hline & N & Mean \\
\hline \multicolumn{2}{l}{ SMS/MMS marketing messages received last month } & \\
GER & 206 & 2.11 \\
FIN & 199 & 2.44 \\
UK & 256 & 3.23 \\
Total & 661 & 2.64 \\
SMS/MMS marketing messages received last month without & \\
permission & & \\
GER & 204 & 0.71 \\
FIN & 198 & 0.40 \\
UK & 250 & 1.42 \\
Total & 652 & 0.89
\end{tabular}

Information such as phone numbers, news, weather forecasts, sports news requested with SMS during the last six months

$\begin{array}{lll}\text { GER } & 205 & 0.39 \\ \text { FIN } & 200 & 6.52 \\ \text { UK } & 253 & 1.77 \\ \text { Total } & 658 & 2.78\end{array}$

Mobile services such as ringtones, logos, screen savers ordered by using SMS during the last six months

$\begin{array}{lll}\text { GER } & 204 & 0.16 \\ \text { FIN } & 200 & 1.37 \\ \text { UK } & 253 & 0.44 \\ \text { Total } & 657 & 0.63\end{array}$

Responded to SMS marketing message by replying to the message (e.g. ordering a product or service or requested more information) during the last six months

$\begin{array}{lll}\text { GER } & 204 & 0.02 \\ \text { FIN } & 200 & 0.34 \\ \text { UK } & 256 & 0.13 \\ \text { Total } & 660 & 0.16\end{array}$

Responded to SMS marketing message by visiting a website or by calling during the last six months

$\begin{array}{lll}\text { GER } & 206 & 0.09 \\ \text { FIN } & 200 & 0.36 \\ \text { UK } & 255 & 0.21 \\ \text { Total } & 661 & 0.22\end{array}$

Participated in TV programs during the last six months

$\begin{array}{lll}\text { GER } & 206 & 0.19 \\ \text { FIN } & 200 & 0.51 \\ \text { UK } & 255 & 0.28 \\ \text { Total } & 661 & 0.28\end{array}$

Participated in SMS sweepstakes or competitions during the last six months

$\begin{array}{lll}\text { GER } & 204 & 0.66 \\ \text { FIN } & 199 & 0.81 \\ \text { UK } & 255 & 0.11\end{array}$

$\begin{array}{lll}\text { Total } & 658 & 0.49\end{array}$ 
Table 2: Construct reliability measures for combined data and subsamples - Cronbach's $\alpha$, composite reliability (CR), and average variance extracted (AVE)

\begin{tabular}{|c|c|c|c|c|c|c|c|}
\hline $\begin{array}{l}\text { Reflective } \\
\text { Construct }\end{array}$ & $\begin{array}{l}\text { Reliability } \\
\text { measures }\end{array}$ & $\begin{array}{l}\text { Combined } \\
\text { Data }\end{array}$ & $\begin{array}{l}\text { FIN } \\
\text { Data }\end{array}$ & $\begin{array}{l}\text { GER } \\
\text { Data }\end{array}$ & UK Data & $\begin{array}{l}\text { Male } \\
\text { Data }\end{array}$ & $\begin{array}{l}\text { Female } \\
\text { Data }\end{array}$ \\
\hline \multirow[t]{3}{*}{ Institutional trust } & Cronbach's $\alpha$ & 0.91 & 0.89 & 0.91 & 0.89 & 0.89 & 0.89 \\
\hline & $\mathrm{CR}$ & 0.92 & 0.92 & 0.93 & 0.93 & 0.93 & 0.92 \\
\hline & AVE & 0.67 & 0.65 & 0.68 & 0.66 & 0.66 & 0.66 \\
\hline \multirow[t]{3}{*}{ Personal trust } & Cronbach's $\alpha$ & 0.89 & 0.90 & 0.91 & 0.84 & 0.89 & 0.88 \\
\hline & $\mathrm{CR}$ & 0.92 & 0.92 & 0.93 & 0.88 & 0.91 & 0.91 \\
\hline & AVE & 0.64 & 0.67 & 0.68 & 0.54 & 0.64 & 0.62 \\
\hline \multirow{3}{*}{$\begin{array}{l}\text { Perceived } \\
\text { control }\end{array}$} & Cronbach's $\alpha$ & 0.81 & 0.68 & 0.89 & 0.83 & 0.83 & 0.78 \\
\hline & $\mathrm{CR}$ & 0.89 & 0.81 & 0.94 & 0.89 & 0.89 & 0.86 \\
\hline & AVE & 0.72 & 0.59 & 0.83 & 0.74 & 0.74 & 0.67 \\
\hline \multirow{3}{*}{$\begin{array}{l}\text { Mobile } \\
\text { Marketing } \\
\text { Permission }\end{array}$} & Cronbach's $\alpha$ & 0.87 & 0.90 & 0.88 & 0.83 & 0.88 & 0.84 \\
\hline & $\mathrm{CR}$ & 0.92 & 0.94 & 0.93 & 0.89 & 0.93 & 0.90 \\
\hline & AVE & 0.79 & 0.83 & 0.82 & 0.75 & 0.81 & 0.76 \\
\hline
\end{tabular}


Table 3: Construct discriminant validity for combined data - squared latent variable correlations (off-diagonal elements) versus average variance extracted (AVE) (diagonal elements)

\begin{tabular}{|l|l|l|l|l|}
\hline & $\begin{array}{l}\text { Institutional } \\
\text { trust }\end{array}$ & Personal trust & $\begin{array}{l}\text { Perceived } \\
\text { control }\end{array}$ & $\begin{array}{l}\text { Mobile } \\
\text { marketing } \\
\text { permission }\end{array}$ \\
\hline Institutional trust & 0.67 & & & \\
\hline Personal trust & 0.47 & 0.64 & & \\
\hline Perceived control & 0.33 & 0.18 & 0.72 & \\
\hline Mobile marketing permission & 0.31 & 0.23 & 0.32 & 0.79 \\
\hline
\end{tabular}


Table 4: Gender differences - group comparison of the influence of institutional trust (INSTRUST), personal trust (PERSTRUST), experience with mobile marketing (EXPMM), and perceived control (CON) on permission for mobile marketing (PER)

\begin{tabular}{|c|c|c|c|}
\hline & $\begin{array}{l}\text { Male model } \\
\text { (n: 359) }\end{array}$ & $\begin{array}{l}\text { Female model } \\
\text { (n: 297) }\end{array}$ & $\begin{array}{l}\text { Path coefficient } \\
\Delta\end{array}$ \\
\hline INSTRUST $\ddagger$ PER & $0.330 * * *$ & $0.514 * * *$ & $0.184^{*}$ \\
\hline PERSTRUST $\ddagger$ PER & $0.136^{*}$ & 0.086 & 0.050 \\
\hline EXPMM $\ddagger$ PER & $0.133 * * *$ & $0.128 * *$ & 0.005 \\
\hline PERCON $\ddagger$ PER & $0.218 * * *$ & 0.025 & $0.193 * *$ \\
\hline $\mathrm{R}^{2}$ & 0.357 & 0.409 & $-/-$ \\
\hline $\mathrm{Q}^{2}$ & 0.337 & 0.317 & $-/-$ \\
\hline
\end{tabular}

$* \mathrm{p} \leq 0.05 ; * * \mathrm{p} \leq 0.01 ; * * \mathrm{p} \leq 0.001$ 
Table 5: National differences - group comparison of the influence of institutional trust (INSTRUST), personal trust (PERSTRUST), experience with mobile marketing (EXPMM), and perceived control (CON) on permission for mobile marketing (PER) in Finland (FIN), Britain (UK), and Germany (GER)

\begin{tabular}{lllllll}
\hline & $\begin{array}{l}\text { FIN } \\
\text { model } \\
\text { (n: 200) }\end{array}$ & $\begin{array}{l}\text { UK model } \\
\text { (n: 260) }\end{array}$ & $\begin{array}{l}\text { GER } \\
\text { model } \\
\text { (n: 207) }\end{array}$ & $\begin{array}{l}\text { FIN-GER } \\
\text { Path co- } \\
\text { efficient } \Delta\end{array}$ & $\begin{array}{l}\text { FIN-UK } \\
\text { Path co- } \\
\text { efficient } \Delta\end{array}$ & $\begin{array}{l}\text { UK-GER } \\
\text { Path co- } \\
\text { efficient } \Delta\end{array}$ \\
\hline INSTRUST $\ddagger$ PER & $0.455^{* * *}$ & $0.444^{* * *}$ & $0.318^{* * *}$ & 0.137 & 0.011 & 0.126 \\
PERSTRUST $\ddagger$ PER & $0.190^{* *}$ & -0.034 & $0.205^{*}$ & 0.016 & $0.224 * *$ & $0.240^{* *}$ \\
EXPMM $\ddagger$ PER & $0.223^{* * *}$ & $0.158^{* *}$ & $0.170^{* * *}$ & 0.053 & 0.065 & 0.012 \\
CON $\neq$ PER & -0.046 & $0.142^{* *}$ & $0.260^{* * *}$ & $0.305^{* * *}$ & $0.188^{* *}$ & 0.117 \\
$\mathrm{R}^{2}$ & 0.440 & 0.294 & 0.552 & $-/-$ & $-/-$ & $-/-$ \\
$\mathrm{Q}^{2}$ & 0.375 & 0.193 & 0.449 & $-/-$ & $-/-$ & $-/-$ \\
\hline
\end{tabular}

$* \mathrm{p} \leq 0.05 ; * * \mathrm{p} \leq 0.01 ; * * * \mathrm{p} \leq 0.001$ 


\section{Appendix 1}

\section{Experience}

a) How many SMS/MMS marketing messages, which advertised a product or service, did you receive on your mobile last month?

b) How many times have you requested information such as phone numbers, news, weather forecasts, sports news with SMS during the last six months?

c) How many times have you ordered mobile services such as ringtones, logos, screen savers by using SMS during the last six months?

d) How many times have you responded to SMS marketing message by replying to the message (e.g. ordering a product or service or requested more information) during the last six months?

e) How many times have you responded to SMS marketing message by visiting a website or by calling during the last six months?

f) How many times have you participated in SMS sweepstakes or competitions during the last six months?

For the following items, respondents used a scale ranging from 1 (strongly disagree) to 7 (strongly agree)

\section{Personal trust}

"I am willing to give my personal information and permission to send mobile marketing to Company X, if"

1. I have had good experience with the company's products/services

2. I have had good experience with the company's previous direct marketing campaigns

3. I have been a longstanding customer of the company

4. A person I am familiar with has recommended the company's mobile services

5. My friends/family members have positive experiences of the company

6. My friends/family members use mobile services from this company

Scale developed based on concepts presented by Bauer et al. (2005); Granovetter (1973);

Coleman (1990), Sztompka (1999); Welter and Kautonen (2005); Zucker (1986); Yamagishi and Yamagishi (1994) and Kautonen and Kohtamäki (2006).

\section{Institutional trust}

7. The company indicates that it adheres to the regulations and codes of best practice that govern mobile marketing

8. The company indicates that it uses customer information only for the purposes approved by the customer

9. I believe that legislation governs the way my personal information is used

10. Mobile marketing is related to a TV or radio programme / advertisement

11. Mobile marketing is related to a newspaper or magazine advertisement

12. I remember seeing the company's advertisements

Scale developed based on concepts presented by McKnight et al. (1998); North (1990); Raiser (1999); Zucker (1986); Li and Miniard (2006) and Sztompka (1999).

\section{Perceived control}

13. I can choose the types of message that I receive (text message, picture message, video message) 
14. I can easily control the number of messages that I receive

15. I can easily cancel the permission to send mobile marketing messages to me

Scale developed based on concepts presented by Kautonen and Kohtamäki (2006) and Vogt (1997).

\section{Permission}

16. I am willing to give my mobile phone number to a company that practises mobile marketing

17. I am willing to provide my background information (e.g. gender, age) to a company practising mobile marketing

18. I am willing to participate in mobile marketing activities

Scale developed based on concepts presented by Bauer et al. (2005) and Tsang et al. (2004). 